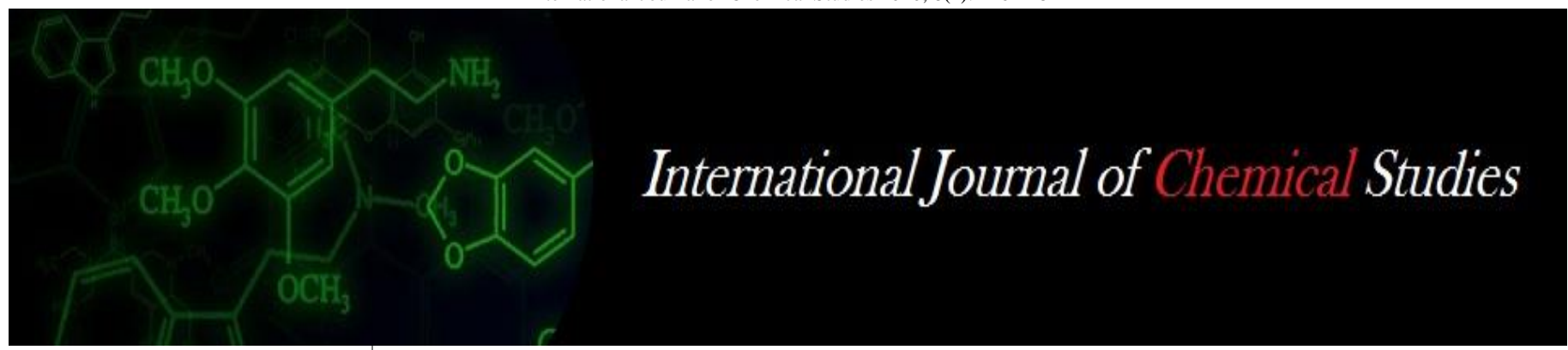

P-ISSN: 2349-8528

E-ISSN: 2321-4902

www.chemijournal.com

IJCS 2020; 8(2): 246-248

(C) 2020 IJCS

Received: 16-01-2020

Accepted: 18-02-2020

Preeti Massey

Post-Doctoral Fellow,

(Genetics \& Plant Breeding),

GBPUAT, Pantnagar, District,

Udham Singh Nagar,

Uttarakhand, India

MK Nautiyal

Professor, (Genetics \& Plant

Breeding), GBPUAT,

Pantnagar, District, Udham

Singh Nagar, Uttarakhand,

India

Corresponding Author:

Preeti Massey

Post-Doctoral Fellow,

(Genetics \& Plant Breeding),

GBPUAT, Pantnagar, District,

Udham Singh Nagar,

Uttarakhand, India

\section{Development of short duration cowpea varieties}

\author{
Preeti Massey and MK Nautiyal
}

DOI: https://doi.org/10.22271/chemi.2020.v8.i2d.8777

\begin{abstract}
Cowpea is an important legume crop grown for grain, green vegetable, fodder and green manuring in India having $20-30 \%$ protein \& minerals. Short duration cowpea varieties maturing in 60-70 days can be cultivated as a niche crop in different cropping systems to harness the maximum income from per unit area of land. Cowpea crop can be grown in tropical and subtropical climates both in plains and upto mid hills. Some improved short duration cowpea varieties have bean developed at Pantnagar University like Pant Lobia-1, Pant Lobia-2, Pant Lobia-3, Pant Lobia-4 \& Pant Lobia-5. These varieties can be sown in spring-summer season under irrigated condition in northern plains from first week of March to 10 April and in kharif season from July to August.
\end{abstract}

Keywords: Cowpea, released, varieties, legumes

\section{Introduction}

Majority of the Indian people are vegetarian and they depend primarily upon grain legumes for dietary protein. Unfortunately the production of grain legumes in India has remained stagnant since 1950 causing decline in per capita availability and widespread malnutrition. This is because most of the good cultivated lands have gone to the green revolution which led 'wheatrice' and 'rice-rice' cropping systems and food legumes have been pushed to marginal lands. Also, the traditional food legume varieties are late in maturity with low yield potential. This has resulted in inadequate protein and minerals in the diets of rural and urban masses on one hand and imbalanced soil fertility due to cereal-cereal rotation on the other hand. Therefore, increased cultivation of pulses is urgently needed. How can this be achieved with the limited land is one of the major challenge of agricultural research. The only answer is to breed and cultivate short duration food legumes in the existing niches between cereal-cereal systems. Wheat is harvested in March-April and rice is transplanted in July leaving about 80-90 days gap in which a short duration food legume can be grown. A number of photo-insensitive and heat tolerant ' 60 -day cowpea' varieties have been recently developed by Pantnagar University which were tested under farmer participatory on-farm trials and All India Multi-location Coordinated Trials.

Cowpea is an important legume crop grown for grain, green vegetable, fodder and green manuring in India. Cowpea is very nutritious as its grain contains $20-30 \%$ protein, minerals like iron, calcium and potash. Short duration cowpea varieties maturing in 60-70 days can be cultivated as a niche crop in different cropping system to harness the maximum income from per unit area of land and to increase he pulse production in the Country. Some improved short duration cowpea varieties have bean developed at Pantnagar University like Pant Lobia-1, Pant Lobia-2, Pant Lobia-3, Pant Lobia-4 \& Pant Lobia-5. These varieties can be sown in springsummer season under irrigated condition in northern plains from first week of March to 10 April and in kharif season from July to August.

Following short duration cowpea varieties have been developed at GBPUAT, Pantnagar.

Pant lobia 1: It matures in 60-70 days in plains and 70-75 days in hills. Plant height is 40-50 $\mathrm{cm}$. \& pod length is $13 \mathrm{~cm}$. It has tolerance to major bacterial and viral diseases like mosaic and attack of aphids and thrips. It needs minimum irrigation and yields over $20 \mathrm{q} / \mathrm{ha}$ grain and $20-25 q /$ ha dry fodder within $65-75$ days. It has $27 \%$ protein. Seed colour is white with black hilum. The sowing time is adjusted so as to avoid rains during crop maturity. 
However, It can be sown from March to first week of September. This variety was released by Uttarakhand State Variety Release Committee during 2008 for cultivation in plains and upto mid hills.

Pant lobia 2: It matures in 70 days in plains and 75-80 days in hills. The plant height is $40-50 \mathrm{~cm}$., pod length is $15-20 \mathrm{~cm}$. The number of seed per pod is 14 to 18 and seed colour is red self. It has tolerance to major bacterial and viral diseases like mosaic and attack of aphids and thrips. It needs minimum irrigation and yields over 14-18q/ha grain and 25-30q/ha dry fodder. It has $30 \%$ protein. The sowing time is March to first week of September. This variety was released by Uttarakhand State Variety Release Committee during 2010 for cultivation in plains and upto mid hills.

Pant Lobia 3: Pant Lobia-3 (IT 889-1) was identified in the annual group meeting of Arid legume project (ICAR) held at Pattambi, Kerla on 26-27May, 2012 as a grain type, high yielder adaptable to Zaid and Kharif season. It is photo-insensitive, pod borer resistant and drought tolerance. Its pod can be harvested ones. Pant Lobia-3 is getting poular in states of Uttarakhand, U.P., karnataka, M.P., Kerala and J\&K.

Pant lobia 4: It matures in 60 days in plains and 40-50 days in hills. The plant height is $40-50 \mathrm{~cm}$., pod length is $14-16 \mathrm{~cm}$. The number of seed per pod is 12 to 14 and seed colour is white. It has tolerance to major bacterial and viral diseases. It needs minimum irrigation and yields over $14-18 \mathrm{q} / \mathrm{ha}$ grain and $25-\mathrm{q} /$ ha dry fodder. It has $25 \%$ protein. The sowing time is March to first week of September.

Pant lobia 5: It matures in 65-70 days in plains and 75-80 days in hills. The plant height is $48-52 \mathrm{~cm}$., pod length is 16$18 \mathrm{~cm}$. The number of seed per pod is 12 to 14 and seed colour is light brown. It has tolerance to yellow mosaic. It needs minimum irrigation and yields over $16-20 \mathrm{q} / \mathrm{ha}$ grain and 15$20 \mathrm{q} /$ ha dry fodder. It has $25 \%$ protein. The sowing time is March to first week of September.

These varieties are short duration, have 60-70-day maturity, dwarf plant type, high grain yield, are rich in protein, iron and zinc. Being short duration, they can be fitted well in different cropping sysyems mainly wheat-rice cropping systems.

Table 1: Description of the five varieties of cowpea

\begin{tabular}{|c|c|c|c|c|c|}
\hline Varieties & Pant Lobia-1 & Pant Lobia-2 & Pant Lobia-3 & Pant Lobia-4 & Pant Lobia-5 \\
\hline Plant type & $\begin{array}{l}\text { Erect plant type with } \\
\text { early and synchronous } \\
\text { maturity. }\end{array}$ & $\begin{array}{l}\text { Semi-erect plant type with } \\
\text { early and synchronous } \\
\text { maturity. }\end{array}$ & $\begin{array}{l}\text { Erect bush plant type } \\
\text { with early maturity. }\end{array}$ & $\begin{array}{c}\text { Erect bush plant type } \\
\text { with early maturity. }\end{array}$ & $\begin{array}{c}\text { Erect bush plant type } \\
\text { with early maturity }\end{array}$ \\
\hline Foliage & Moderate foliage mass & High foliage mass & $\begin{array}{l}\text { Light green with } \\
\text { higher foliage mass }\end{array}$ & Light green & Light green \\
\hline Flower colour & White & Purple & Purple & White & Dark purple \\
\hline Days to $50 \%$ flowering & $40-45$ & $45-50$ & $40-45$ & $40-45$ & $40-45$ \\
\hline Immature Pod colour & $\begin{array}{c}\text { Green with purple tinge } \\
\text { at tip }\end{array}$ & Light green & Green & Purple & Light green \\
\hline Mature Pod colour & straw & straw & straw & straw & straw \\
\hline Pod Length $(\mathrm{cm})$ & 13 & $15-20$ & $16-18$ & $14-16$ & $16-18$ \\
\hline Seeds/pod & $14-18$ & $14-18$ & $14-16$ & $12-14$ & $12-14$ \\
\hline Seed colour & White & Red & Dark Brown & White & Brown \\
\hline Seed size & Medium & Medium & Medium & Medium & Bold Large \\
\hline Hilum colur & Black & Very thin black lining & Black & Black & Black thin lining \\
\hline Protein content in grain & 27 & 30 & 27 & 25 & 25 \\
\hline \begin{tabular}{|l|} 
Photosensitivity \\
\end{tabular} & Photo insensitive & Photo insensitive & Photo insensitive & Photo insensitive & Photo insensitive \\
\hline Days to maturity & 60-70 days & $65-75$ days & $65-70$ days & 60-65 days & 65-70 days \\
\hline Yield potentiality & $20 \mathrm{q} / \mathrm{ha}$ & $25 \mathrm{q} / \mathrm{ha}$ & $18-20 \mathrm{q} / \mathrm{ha}$ & $14-18 \mathrm{q} / \mathrm{ha}$ & $16-20 \mathrm{~g} / \mathrm{ha}$ \\
\hline $\begin{array}{l}\text { Resistance to biotic } \\
\text { and abiotic stresses }\end{array}$ & $\begin{array}{c}\text { High level of resistance } \\
\text { to major fungal, bacterial } \\
\& \text { viral diseases. }\end{array}$ & $\begin{array}{c}\text { High level of resistance to } \\
\text { major fungal, bacterial \& } \\
\text { viral diseases. }\end{array}$ & $\begin{array}{l}\text { High level of } \\
\text { resistance YMV and } \\
\text { Bacterial Blight. }\end{array}$ & \begin{tabular}{|c|} 
High level of \\
resistance to CYMV \\
and Bacterial Blight.
\end{tabular} & \begin{tabular}{|c|} 
High level of \\
resistance to CYMV \\
and Bacterial Blight.
\end{tabular} \\
\hline
\end{tabular}

Cowpea requires well drained sandy loam soil. It can also be grown in other types of soil with $\mathrm{pH}$ range of 6-7 where cultivation of other legume crops is not possible.

Though it can be grown under zero tillage after wheat harvesting, if possible deep ploughing followed by two harrowings and then levlling of the field should be done. Farmyard manure@10 tons/ha or vermicompost @ 2 tons/ha should be incorporated in the field during field preparation. Chemical fertilizers like nitrogen @ 20-30 kg,60 kg/ha. phosphorus and $50 \mathrm{~kg}$ potash /ha should be applied in the field before last harrowing. For better growth of the crop farmyard manure@10 tons/ha or vermicompost@ 2 tons/ha should be mixed well in the soil well before sowing.

Cowpea is sown in rows spaced $40-50 \mathrm{~cm}$ apart with plant to plant distance $10 \mathrm{~cm}$. Seed should be sown at $2-3 \mathrm{~cm}$ depth. Proper moisture should be ensured at the time of sowing. For spring-summer season best sowing time under irrigated condition in northen plains is 15 March to 10 April. In southen India sowing can be done in January - February for spring summer season. The seeds can be sown during JulyAugust months for Kharif crop. For grain cowpea the sowing time should be adjusted so as to avoid the rains at maturity. Rains at maturity cause severe damage to the crop.

Seed rate depends upon the size of the seed \& germination percentage. Generally $20-25 \mathrm{~kg}$ seeds/ha for grain/vegetable type cowpea and $35-40 \mathrm{~kg} / \mathrm{ha}$ for fodder varieties is required. It is advised to treat the seeds with thirum @ $3 \mathrm{gm} / \mathrm{kg}$ seeds to have better germination and protection of crop from soil born diseases in early stage of the crop.

The weed compete the cowpea crop for nutrition from soil specially during early stage of the crop. Therefore, two hand weedings/hoeings are required, first at 20-25 days after sowing and second at 40-45 days after sowing to keep the cowpea field clean. To save the labour cost weedicide like Pendimethilin can be sprayed @ $1 \mathrm{~kg}$ a.i./ha after sowing followed by one hand weeding 30-40 days after sowing. 


\section{Conclusion}

To solve the pulse problem in the country, cultivation of short duration pulse crops like cowpea and moong is of foremost important must. The grain cowpea varieties developed at Pantnagar can be grown successfully in the niche of wheatrice cropping system as these require 60-70 days for maturity and produce 15-20 q/ha grain. The cultivation of these cowpea varieties will lead to increase the production of legumes in the state.

\section{References}

1. Cisse N, Hall AE. Importance of traditional cowpea (Vigna unguiculata [L.] Walp.) In Senegal, a case study. (Eds.). D. L. Wrench and M. Ebbert, 2010, 1-27.

2. Omo-Ikerodah EE, Fatokun CA, Fawole I. Genetic analysis of resistance to flower bud thrips (Megalurothrips sjostedti) in cowpea (Vigna unguiculata [L.] Walp.). Euphytica. 2009; 165(1):145-154.

3. Kamara AY, Chikoye D, Ekeleme F, Omoigui LO, Dugje IY. Field performance of improved cowpea varieties under conditions of natural infestation by parasitic weed Striga gesnerioides. International Journal Pest Management. 2008; 54(3):189-195.

4. Hall AE, Singh BB, Ehlers JD. Cowpea breeding. Plant Breeding Review. 1997; 15:215-274.

5. Omo-Ikerodah EE, Fatokun CA, Fawole I. Genetic analysis of resistance to flower bud thrips (Megalurothrips sjostedti) in cowpea (Vigna unguiculata [L.] Walp.). Euphytica. 2009; 165(1):145-154. 